\title{
Populist Eurosceptic trajectories in Italy and the Netherlands during the European crises
}

Politics, forthcoming (version accepted on 29-01-2018)

Andrea L. P. Pirro

Scuola Normale Superiore

andrea.pirro@sns.it
Stijn van Kessel

Queen Mary University of London

s.vankessel@qmul.ac.uk

\begin{abstract}
Multiple crises shook the European Union (EU) during the past decade. First, the economic and financial crises that unfolded since 2008 shook the foundations of the European project and its monetary union. Then, the inflow of migrants and asylum seekers into Europe in 2015 questioned the EU's ability to jointly respond to common political issues. More recently, Brexit came across as the corollary of a prolonged legitimacy crisis. These crises are have not only affected the course of European integration, but also provided novel issues for political competition within the EU member states. At the party-political level, populist antiestablishment parties have traditionally listed among the principal interpreters and drivers of criticism towards 'Europe'. In this article, we empirically address the changing Eurosceptic frames adopted by populist parties during these crises, and speculate on the reverberation of these frames in respective party systems. For this purpose, we focus on two cases: Italy and the Netherlands. Both countries present instances of populist parties of different ideological persuasions within traditionally Europhile contexts. At the same time, both countries have been affected to very different extents by the recent crises, allowing us to examine how populist parties have responded to different political opportunities.
\end{abstract}

Keywords: Populism; Euroscepticism; Crisis; Political parties; Frames 


\section{Introduction}

Populist parties have made significant electoral inroads and are now integral part of European party systems. They pose not only a challenge to political elites at the national level, but also to the process of European integration. From a populist perspective, the EU can be interpreted as the ultimate elitist project, operating against the general will of the people, and according to non-democratic practices (e.g. Canovan, 1999). Populist organisations have been also considered 'movements of crisis', linking their emergence and fortunes to real or perceived crises (Taggart, 2000). As explained in the introduction of this Special Issue, the occurrence, in close sequence, of the 'Great Recession', the migrant crisis, and 'Brexit' gives us the opportunity to ascertain whether this holds in practice.

By studying four Eurosceptic populist parties in Italy and the Netherlands this contribution seeks to advance the debate on this topic in a number of respects. First, by looking at the way populists framed Europe and its crises, we intend to ascertain if discourses effectively overlapped - and, if not, why. As crises are porous and fuzzy events, and primarily 'performed' by populists (Moffitt, 2015), disentangling the mechanisms in place at these stages represents a meaningful way forward to understanding the relationship between populist parties and crises. Second, through the analysis of populist Eurosceptic frames in times of crisis, we set out to investigate whether the nature of oppositional discourses changed substantially over time in reaction to critical events. Finally, we devote some remarks to the reciprocal influence exerted by populist Eurosceptic actors at the end of our discussion.

The article is structured as follows. First, we outline the rationale for our case selection, the main expectations, and the analytical strategy. Second, we look at the evolution of populist Eurosceptic discourses in the face of the multiple crises. Finally, we draw some comparative conclusions on the basis of our findings and briefly elaborate on the question of populist Eurosceptic impact across the two party systems. We find that all European crises provided ammunition for populist actors to emphasise their disenchantment with the process of European integration. While all of our cases started out as soft-Eurosceptic in the pre-crises years, some clearly hardened their Euroscepticism. However, the reactions of the populist parties and their framing of the various crises still varied, depending on their ideological characteristics, and also the way the crises have played out in their particular contexts. 


\section{Rationale and methodology}

From a comparative perspective, the two selected countries are interesting in that they a) demonstrate contextual differences in 'northern' and 'southern' Europe, and b) host electorally relevant populist parties of various kinds. While the first criterion should unravel differentiated populist responses across countries, the second should highlight how these responses were articulated among populist parties of different ideological persuasions.

The Great Recession and the migrant crisis have affected both countries in different ways. While the Netherlands certainly felt the consequences of the economic crisis, its unemployment figures and government debt to GDP ratio remained roughly half the size of Italy's, and the Italian economy experienced worse negative growth figures (Eurostat, 2016). Concerning the migrant crisis, Italy has been a key point of access for immigrants, whereas the Netherlands can be listed among countries of eventual destination (Economist, 2016). The cases thus allow us to examine how populist parties have reacted to different context-driven political opportunities. That is, populist parties' responses can be expected to vary due to the different salience as well as effects of each crisis in both countries.

The Italian and Dutch party systems both include populist parties that have opposed 'Europe' through different ideological lenses. We can include the Italian Northern League (LN) and the Dutch Party for Freedom (PVV) in the populist radical right party family, describe the Dutch Socialist Party (SP) as radical left, while the Italian 5 Star Movement (M5S) defies straightforward categorisations in terms of left and right: the M5S started out as an antiestablishment party with left-libertarian concerns, but increasingly adopted nativist tones. This selection allows us to assess how populist parties of various kinds have reacted to the multiple European crises. It can, for instance, be expected that the 'Great Recession' was a salient theme for left-wing parties in particular, in view of their primary concern with socioeconomic issues, while populist radical right parties, generally more concerned with cultural issues, concentrated mainly on the migrant crisis. As Brexit has typically been associated with themes of sovereignty and democracy, it could arguably entice all types of populist parties.

Although we anticipate a variety of specific responses due to these ideological and contextual differences, we generally expect socioeconomic arguments to have become dominant during the Great Recession, cultural arguments during the migrant crisis, and legitimacy and/or sovereignty arguments amid Brexit. On the whole, we interpret crises as a catalyst for particular frames, which may coexist with other traditional/pre-existing arguments against Europe. 
Drawing on social movement theory, we resort to the notion of frames to explain the construction of collective identities and the creation of alternative systems of meaning at the public level (e.g. Snow et al., 1986). The use of frames fulfils a symbolic function, punctuating and connecting 'patterns or happenings in the world' (Snow and Benford, 1992: 138). We interpret them as the discursive stratagem to link populist Euroscepticism to the crises that unfolded during the past decade. In times of crisis, populist parties can use Eurosceptic frames as 'interpretative schemata' to single out an existing social condition or aspect of life, and define it as unjust and deserving of corrective action (Snow and Benford 1992: 137). Far from static, populist Eurosceptic frames are liable to continuous redefinition and adjustment. For this reason, we set to analyse the evolution of frames across time and, in fact, across crises.

Acknowledging limitations in the categorisation of Eurosceptic frames in the extant literature (e.g. Helbling et al., 2010), we set to square the discourse of populist parties within four main frame categories. First, socioeconomic frames link Euroscepticism to economic and financial arguments, such as the mishandling of the sovereign debt crisis, and generally all those (negative) consequences attached to EU or Eurozone membership. Second, cultural frames link Euroscepticism to the issue of immigration and the security threats posed by (Muslim) 'aliens'. Finally, sovereignty and legitimacy are typical oppositional frames deployed by populists. The former relates to the observation that European integration curtails the sovereignty of member states. Regarding the latter, populist Eurosceptics emphasise the democratic deficit underpinning the EU and question the legitimacy of decisions taken by supranational (unaccountable) elites (Table 1).

Table 1. Populist Eurosceptic frame categorisation

\begin{tabular}{l|l}
\hline Socioeconomic & $\begin{array}{l}\text { Economic and financial arguments, fiscal sovereignty, banks, bail-outs, } \\
\text { national debt, Euro } \\
\text { Immigration, multiculturalism, Christianity, Islam, security }\end{array}$ \\
Sovereignty & $\begin{array}{l}\text { Delocalisation, transfer of decision-making, centralisation } \\
\text { Legitimacy }\end{array}$ \\
\hline
\end{tabular}

These frames are not necessarily mutually exclusive. For instance, the free movement of labour is a topic that can be simultaneously framed in socioeconomic (threat to national workers' position) and cultural (disturbance of social homogeneity) terms. Further, the legitimacy of the 
EU may be directly related to supposed failures in economic or cultural policy areas (see Scharpf, 1999). We nevertheless deem the identified frames as useful heuristics to assess the EU-related discourse of populist parties. Within these categories, we set out to ascertain whether populist Eurosceptics effectively identified a problem and assigned blame for the unfolding of crises; and advanced solutions or particular courses of action. These are elements defined in social movement theory as 'diagnostic' and 'prognostic' framing, respectively (Snow and Benford, 1988). A third framing activity ('motivational'), not directly relevant to our analysis of party discourses and positions, pertains to the rationale for action/inaction.

We use qualitative content analysis of official party materials to reconstruct populist Eurosceptic frames. We start out from the frame categorisation presented in Table 1 and qualitatively assess the prominence of each frame amid each crisis. In order to respond to the (time-sensitive) challenge posed by the emergence of multiple crises, we combine evidence from different data sources. While prioritising the analysis of official programmatic documents for national and European Parliament (EP) elections, we resorted to additional sources in order to assess parties' reactions to events occurring outside of election periods. In the case of Italy, we analysed news items appearing on the LN's website between 2014 and 2016, and on Beppe Grillo's blog (i.e. the M5S's official website) between 2007 and 2016. In the case of the Netherlands, we similarly made use of news items posted on party websites, as well as party newsletters (period: 2014-2016). These sources also included summaries of MPs' contributions to parliamentary debates.

\section{Who is what? Identifying the populist Eurosceptics}

Populism in Italy has been associated with the activities of mainstream as well as peripheral parties (e.g. Tarchi, 2015). Silvio Berlusconi's political incarnations (i.e. Forza Italia, FI, 19942009, and again since 2013; The People of Freedom, PdL, 2009-2013) are examples of alleged mainstream populism (e.g. Verbeek and Zaslove, 2016). Since neither FI nor PdL ever quite qualified as Eurosceptic organisations, however, they are irrelevant to our enquiry.

The identification of the LN and the M5S as populist Eurosceptic actors is less contentious. The LN has, ever since its establishment in the early 1990s, centred its political activity on the defence of the 'common (Northern) man' against 'Roma ladrona' (the bad central elite). While the LN did not lose its regionalist appeal, the LN progressively shifted from ethnoregionalism to nativism and authoritarianism by including xenophobia and 'law and order' in its discourse (Ignazi, 2005). It also intensified its opposition to Europe once the prospects for 
the autonomy of Padania within the EU framework waned (Huysseune, 2010). The LN stressed the need to protect national customs and values from European integration, and criticised the adoption of the Euro, the unrestrained opening of markets, and the Eastern enlargement elements that ostensibly played at the detriment of Padanian enterprises (LN, 2004).

The M5S organised as a full-fledged party in 2009 and its rise can be partially linked to the multiple crises endured by the EU in recent years (e.g. della Porta et al., 2017). The fate and political outlook of the party and its leaders (Beppe Grillo and the late Gianroberto Casaleggio) are closely knit (e.g. Tronconi, 2015). Since 2005, Grillo has made consistent use of his blog as the primary channel to move anti-establishment attacks to the 'caste', often presenting himself as the 'megaphone' of the voiceless. Advocating an unmediated form of democracy, he claimed that the M5S 'wants citizens to become State', aspiring 'common people with a clean record' to enter the Parliament and overthrow those (i.e. the elites, the establishment) who 'will never surrender' (Grillo, 2011a). The manifesto released upon party formation (M5S 2009) - to this date, the only comprehensive programmatic document to be released - essentially presented the M5S as a post-materialist organisation concerned with ecology and direct democracy. Antiimmigration stances, salient in the party discourse and in line with the nativist positions of the populist radical right, have been exclusively articulated outside official documents. Absent in the years prior to the crises, our analysis will show that the M5S gradually developed a pronounced Eurosceptic profile.

Similar to the Italian cases, populist parties in the Netherlands are also characterised by ideological diversity (Lucardie and Voerman, 2012). The SP was founded in 1971, but entered the Dutch parliament only in 1994, after it departed from staunch communist doctrines and adopted a more populist discourse, which blamed the entire political establishment for subscribing to neoliberalism and the free-market ideology. The SP declared it wanted the people, not the market, to decide over the future (SP, 1998: 3). While the SP is still regularly identified as a populist party (e.g. Schumacher and Rooduijn, 2013; Akkerman et al., 2014), it is evident that populism has become a more irregular element in the party's discourse over the years (Lucardie and Voerman, 2012). The party nevertheless continued to perceive certain social ills through a populist lens. Its manifesto from 2010, for instance, argued that politicians had failed and that the interests of 'the citizens' played a decreasing role in politics (SP, 2010: 5, 11); the version of 2017 similarly denounced the 'politics of the elites' (SP, 2017: 5). As far as European integration is concerned, the SP has described the EU as an undemocratic and neoliberal project that served the interests of large companies, while threatening working conditions and social rights (e.g. SP, 1998). 
Geert Wilders' PVV has established itself as the dominant populist radical right force in the Netherlands since its entry into parliament in 2006. Wilders blamed political elites for a raft of social problems, not least related to the spread of multiculturalism and 'Islamisation' of Dutch society (Vossen, 2011). Established politicians were, furthermore, accused of disregarding the concerns and interests of ordinary citizens. In addition, the PVV has, from its early days onwards, described the EU as an undemocratic 'super state', and lamented the handing over of sovereignty to Brussels bureaucrats (e.g. Wilders, 2005). The PVV also opposed financial transfers to the EU, the opening of borders to Eastern European labour migrants, and Turkish EU-membership.

\section{Eurosceptic frames in the face of the recent European crises}

Besides their populist profile, the parties included in this study displayed different shades of (soft) Euroscepticism prior to the unfolding of the various European crises; none proposed to end the EU membership of their country. We now set out to investigate how they responded to the crises identified above.

\section{The Great Recession}

In the wake of the Great Recession, the LN - then junior partner in the government coalition led by Berlusconi - did not specifically blame the EU for the unfolding of events; the economic and financial crisis was either labelled as 'global' or 'international'. Responsible for multiple imbalances, 'financial globalisation (promoted and carried out by the world of high finance)' supposedly triggered a crisis of global scale (LN, 2009: 53). While the diagnostic framing was clearly defined along socioeconomic lines at the peak of the Great Recession, the crisis was also associated with a crisis of values, ideas, and ideals - i.e. 'globalisation without values' (LN, 2009: 53-54). LN's prognosis contemplated keeping enterprises alive, partly through protectionist measures to be introduced at the EU level (LN, 2009: 53-55).

The LN's soft-Eurosceptic frames continued to extend to the cultural, sovereignty, and legitimacy spheres. The party argued that European integration had created a 'continental super-state, whose level of democracy is, in practice, non-existent', and threatened 'its peoples and European traditions' (LN, 2009: 60-61). The LN aspired to a 'confederal' EU, in which member states could preserve their sovereignty and see cultural differences recognised. A cultural framing dominated the LN's reading of non-procedural aspects related to Europe, referring in particular to the Christian roots of Europe (LN, 2009: 62-63). 
The economic and financial crisis were not mentioned in the 2013 election manifesto not even from an anti-globalist perspective. What is more, the party had virtually dropped its Eurosceptic discourse by reinstating the role of Italy within Europe; advancing proposals to overcome the politics of austerity by crafting a political, economic, and fiscal union (LN, 2013: $3)$.

However, the election of Matteo Salvini to new federal secretary (December 2013) marked a clear step towards the systematic delegitimisation of the EU. In the 2014 European manifesto, the legitimacy and sovereignty frames partly overlapped with each other. The document highlighted the EU's democratic deficit, whereby the sovereign people of individual member states were considered to have lost out from the EU's lack of accountability. The LN's prognosis was to bring back the people at the centre of the European project by clarifying the roles of the EU and member states, ratifying treaties by means of referendums, and tying EU activities to national and European parliaments' control (LN, 2014a: 3-5). In addition, the LN sought to regain complete national primacy regarding, among others, monetary and fiscal matters (LN, 2014a: 5-6). The cultural framing of Europe also emerged from the portrayal of the EU as a 'globalist' actor threatening local traditions and diversity (LN, 2014a: 30).

The real turning point in the LN's Eurosceptic trajectory is however the elaboration of a socioeconomic framing of Europe, which linked for the first time the economic and financial crisis to Italy's Eurozone membership - and, though secondarily, to the mismanagements in the world of banking and finance. The LN's key plan of action was captured by its slogan: 'Out of the Euro. Now!'.

The imposition of a single currency for the different economies of the EU member states has effectively deprived Europe of the principal instrument to face the dramatic effects of the economic crisis burst in the US in 2008. ... Without monetary control, a state in recession cannot try to counter crises. Without monetary control, a state cannot have any autonomy and turns into a Third World country.... The Euro is today recognised by many European and international economists as a failed experiment. (LN, 2014a: 15)

The LN sought to regain competitiveness by returning to 'our' currency and directly administering monetary policies at the national level (LN, 2014a: 15). In 2014, the party also issued a document titled Enough with the Euro. How to Exit the Nightmare, in which it directly linked the common currency to the crisis, articulating 31 ways to achieve 'another Europe' (LN, 2014b).

Beppe Grillo, the leader of the M5S, elaborated on political and financial crises of various sorts on his blog. The Global Financial Crisis appeared rather early in his critique, without 
however taking Eurosceptic tones. Blame was instead directed at banks and their connivance with political powers (e.g. Grillo, 2009a, 2009b). Although Grillo had already noted how EU funds were allocated through shady procedures (Grillo, 2007), the role of Europe in the crisis did not dominate his discourse. The articulation of monetary arguments in relation to Eurozone membership and the Great Recession only started in 2011 (Grillo, 2011b). Grillo then gradually came to question the foundations of the EU, including the Euro, and oppose the idea of a Banking Union (Grillo, 2011c).

By the end of 2011, the M5S held an internal referendum on withdrawal from the Eurozone (Grillo, 2011d). Grillo specified how it was possible to remain within the EU while reverting to national currencies - noting how the crisis had mostly affected Eurozone countries: 'It's not about principled hostility to the Euro, but being able to afford it. In order to remain in the Eurozone, we are starving the country' (Grillo, 2012). Grillo's blog then either conducted or reported a series of interviews with prominent Eurosceptic figures (e.g. Grillo, 2013a, 2015b), which bridged the socioeconomic, legitimacy, and sovereignty framings of Euroscepticism. Successive campaigns adopted the slogan 'out of the Euro' and focused on defining the course of action for exit, while framing permanence within the Eurozone in terms of a 'choice between life and death' (Grillo, 2014a).

Other than the two Italian cases, the Dutch SP did not radicalise its position on Europe much during the financial and economic crises. In its manifesto for the 2009 EP elections, the party listed its traditional grievances with European integration, using concomitantly socioeconomic, legitimacy, and sovereignty frames. The SP criticised other parties for supporting the current form of European integration, which had made Europe 'one big market place', where 'economy trumps democracy time and time again' (SP, 2009: 7). The party further referred to the Constitutional Treaty, which was rejected in 2005 by Dutch voters in a referendum. The Treaty had supposedly 'threatened to turn the Netherlands into a powerless province in an undemocratic and a-social European super state (SP, 2009: 7) and the SP complained that voters were not given a second chance to vote on the new Lisbon Treaty.

Thus, in the wake of the Great Recession, the SP's soft-Eurosceptic discourse on Europe was marked above all by continuity. The crisis was not left unmentioned, however, and the SP partly blamed the EU, claiming that 'Brussels has chosen the entirely wrong path of more market and ever less protection of the public good' (SP, 2009: 43). In terms of prognostic framing, the SP suggested that the freedom of bankers, investors and large companies had to be limited, for instance by means of stricter regulation of the global financial markets. 
The 2010 national election manifesto devoted relatively little attention to the EU. The party argued that the crisis of 'casino capitalism' implied a 'painful unmasking of the political and economic elites', but blamed the crisis on bankers, shareholders, and managers rather than on the EU (SP, 2010: 5). In its manifesto for the early 2012 election, the SP's diagnosis was similar; the party criticised the fiscal rules and austerity measures imposed by Brussels, but did not hold the EU responsible for the crisis as such (SP, 2012: 65). The 2014 EP election manifesto struck a different tone: the banking crisis was deemed 'the direct consequence of the neoliberal policy characterising the EU since the 1990s' (SP, 2014: 5).

Despite some inconsistencies concerning blame attribution, the SP clearly continued to address the malign economic consequences of European integration. The lack of democratic legitimacy and loss of sovereignty also remained recurring themes. Indeed, in 2014 the party argued that ' $[\mathrm{t}]$ he current crisis is abused to accelerate the process towards a European federation' (SP, 2014: 9). At the same time, however, the party called for a greater coordination between the economic policies of EU and Eurozone members as a means to counter the crisis (SP, 2012: 65); a greater role for the European Central Bank (ECB) in stimulating employment; and a European-wide regulation of financial markets (SP, 2012: 60). These proposals, along with pleas for closer cooperation concerning cross-border problems and protection of labour rights, appeared somewhat at odds with the SP's more general denunciation of 'Brussels' interference'.

The radical right PVV has been less ambiguous about its position on Europe. The party acknowledged the value of economic and trade cooperation, but has been wary of other forms of integration. The use of multiple frames remained a consistent feature of the party's EU discourse, although the party made a more explicit link between European integration, immigration, and multiculturalism from 2010 onwards. The EU was dubbed a 'multicultural super state', and the party complained that 'thanks to that club in Brussels, Europe is swiftly turning into Eurabia' (PVV, 2010: 13).

The main discontinuities in the PVV discourse relate to the tone and intensity of its opposition to Europe over time (e.g. Van Kessel and Castelein, 2016). Much more so than before, the issue took centre stage in the programme of 2012, which was titled 'Their Brussels, our Netherlands'. It was also at this time that Wilders explicitly began to criticise the EU's handling of the financial and economic crisis. Indeed, Wilders' central argument for previously withdrawing support from the incumbent minority government, and triggering the 2012 election, centred on opposition to the austerity measures proposed to comply with Brussels' budget rules. The 2012 manifesto contained a multitude of disparaging comments about 
partying 'EU-nationalists' enjoying 'ever-lasting lunches', 'blind inhabitants of the ivory towers in Brussels', and Dutch politicians slavishly following the orders of their European 'masters' (PVV, 2012: 11).

The PVV's criticism of the EU remained multifaceted, although the manifesto included various references to the crisis, in particular related to the financial transactions to member states in Eastern and Southern Europe. Overall, the Great Recession ostensibly encouraged Wilders to increase the salience of European integration, and to make Euroscepticism a central theme of his party's campaign. The party's prognostic framing also changed in 2012; for the first time, the PVV proposed to end Dutch membership of the EU and the Eurozone, thus moving from soft to hard Euroscepticism. The party maintained its hard-Eurosceptic course prior the EP elections of 2014 and national election of 2017 (PVV, 2014; 2017a), although Wilders' focus had largely shifted away from the EU in the latter campaign. Notably, apart from a reference to Europe's open borders, clear-cut Euroscepticism was also lacking in Wilders' official response to the coalition agreement reached between four rival parties in October 2017 (PVV, 2017b).

Across our four cases, the Great Recession certainly had a considerable impact. Irrespective of domestic context and ideology, all populist parties highlighted structural flaws in the EU in their analysis of the Eurozone crisis and economic downturn. The SP's discourse was the steadiest in this regard: socioeconomic issues had always been the party's main concern. The intensity of the other parties' criticism of the EU fluctuated - ostensibly depending on party leadership strategies - and remained more multifaceted. It is also notable that socioeconomic arguments gained strength with some delay after the outbreak of the Eurozone crisis.

\section{The migrant crisis}

As far as the migrant crisis is concerned, Italy has been exposed to grand-scale migratory flows already before 2015. This partly explains why the LN already denounced a 'boom' of arrivals to Italian shores in 2013, and framed immigration as a problem for national security. At first, the LN asserted the need for tighter cooperation between European police forces and border patrol units - though independently from Brussels (LN, 2014a: 29). Somewhat inconsistently, the LN later blamed the EU for the poor involvement and effectiveness in the management of non-EU immigration, proposing to counter illegal immigration 'at the source', and claiming that the entire onus should rest on the EU (LN, 2015a: 11). The LN further demanded substantial revisions to the Dublin III Regulation, which determines asylum applications to be processed in the EU country of entry (LN, 2015a: 14). 
The issue of immigration and security only gained new impetus with the advancement of Islamic State and in the wake of the Paris attacks of January 2015, virtually linking the populist Euroscepticism of the LN to legitimacy and cultural frames. The crisis mainly served to bridge the issue of security - now escalated from criminality to terrorism - with immigration. The party denounced the mismanagement of uncontrolled immigration: 'The EU should abandon the carelessness of its political activity, and return to stress and defend its roots' (LN, 2015b).

Yet, the blaming of the EU during the migrant crisis has been at best marginal. News items issued between 2014 and 2016 only sporadically referred to the EU. The European Commission's proposal to distribute migrants more evenly across member states was, nevertheless, interpreted as another disaster crafted by the EU (LN, 2015d). The LN endorsed the Hungarian government's decision to close down borders and build a fence in Summer 2015, which was congruent with its aspiration to defend nation states against the diktats of EU bureaucrats, and to prevent 'the death of the European culture' (LN, 2015e).

As in the case of the LN, the question of illegal immigration appeared in the M5S's discourse before the crisis took a pan-European breadth (e.g. Grillo, 2013b); the party often dubbed Italy the 'refugee camp of Europe'. The bulk of the party's criticism targeted the Dublin Regulation signed by Berlusconi and the LN - a leitmotiv throughout the migrant crisis. The M5S proposed to relocate humanitarian aid towards the countries of departure, and lift the burden imposed on countries of first arrival (Grillo, 2014b). The party further criticised EU institutions for their decisional stalemate (Grillo, 2015c), and denounced the selfishness of member states that arbitrarily decided to suspend the Schengen Agreement (Grillo, 2015d). In reaction to the EU's laxness, the M5S proposed to limit the issuing of residence permits on humanitarian grounds, introduce a system of forced repatriation, and increase the surveillance of asylum seekers (Grillo, 2015e). More recently, it also criticised the EU for the agreement on migrants sealed with the Turkish government (Grillo, 2016a).

While the Dutch SP mainly criticised the EU on socioeconomic grounds, the party has nevertheless been sceptical of labour migration, which was deemed to exploit immigrants from Central and Eastern Europe, boost unfair competition for workers at home, and degrade social entitlements and labour conditions (e.g. SP, 2006: 58). As regards asylum seekers, the SP has generally taken a more welcoming stance; the SP also spoke out in favour of European agreements leading to a fair distribution of refugees in case of calamities (SP, 2014: 23). In November 2013, SP MEP Dennis de Jong urged the EU to actively cooperate to offer refugees temporary protection (De Jong, 2013). In October 2015, the party declared its support for 
granting refugees shelter in the Netherlands, but at the same time stressed the need to take seriously the concerns of the local population (SP, 2015). The party also argued that the real solution for the migrant crisis was to be found not in the Netherlands, but in the region of conflict.

The PVV presented a different analysis of the situation. The party had always opposed 'mass-immigration', and in more recent years proposed a 'complete end to immigration from Islamic countries' (PVV, 2010: 15). As the migrant crisis unfolded, the PVV started the campaign 'Borders Closed!' and declared:

The asylum-tsunami from Islamic countries threatens the Netherlands. Everything is at stake: our security, freedom and future. These migrants are not concerned with safety. They were safe already in the countries they passed through. The sheltering of one asylum seeker costs us 36,000 euro per year. Billions of euros are at stake. Money that we can't spend for the benefit of the Dutch anymore. (PVV, 2015a)

The PVV thus framed the migrant crisis in cultural as well as economic terms. In one parliamentary debate, Wilders questioned the legitimacy of welcoming migrants, by reading out letters of citizens complaining about the asocial, obscene, and unlawful behaviour of (male) asylum seekers (PVV, 2015b). Particularly the safety of women was a concern for Wilders, who proposed the 'Islamic testosterone bombs' to be locked up in the asylum seeker centres (PVV, 2016a). Although the PVV leader did not primarily focus on the EU's actions in his diagnosis of the problem, he did hold European leaders responsible, blaming them for forsaking 'our women and daughters' by refusing to close their national borders. As far as issue-solving was concerned, the PVV rebuffed the need for a European plan or a deal with Turkey; the party's solution was simply to close Dutch borders (PVV, 2016b).

The migrant crisis, all in all, had quite a different impact on the discourse of each of our four cases. Ostensibly due to the timing of the migrant crisis in Italy, and the increasing convergence of the LN and the M5S on nativist grounds, the populist Eurosceptic frames of these parties bore a number of similarities, and related primarily to culture and legitimacy. The EU was both blamed for inaction and taking wrong measures, placing disproportional pressure on Italy. The Dutch SP showed a more welcoming stance towards asylum seekers and could not genuinely be deemed Eurosceptic when it came down to this issue. The PVV, on the other hand, showed no solidarity with (Islamic) migrants at all. The party lamented the EU's open borders and opposed EU interference as far as solving the crisis was concerned. 


\section{Brexit}

In reaction to the Brexit vote, the LN claimed to have always stood up for the European people's ability to choose between death by European rules or rebirth through sovereignty: 'The strong powers have lost, the sovereign people have chosen and defeated them' (LN, 2016a). The Brexit referendum was used as a lens to filter internal affairs and undermine the Italian referendum on constitutional reform proposed by PM Renzi that took place in December 2016. Campaigning on the 'no' side, the LN drew parallels between opposition to Renzi's proposed reforms and the British call for democracy through the UK referendum (LN, 2016a). The LN accordingly tried to turn the result of the UK referendum against the pro-European government - and, thus, use it for internal purposes. While the Brexit referendum was deemed a great display of freedom, 'the real question now is whether democracy is compatible with Europe. We have been the only ones to vote against the Fiscal Compact and support the Europe of peoples' (LN, 2016b). Hence, amid sovereignty and legitimacy frames, Brexit has been also defined in socioeconomic terms. In particular, the British people were seen to have chosen freedom without subduing to the world of financial lobbies, on the one hand, and the Europe of banks and multinationals, on the other (LN, 2016c).

The M5S anticipated the Brexit referendum bearing deflagrating consequences for the institutional setup of the EU - regardless of its eventual outcome. Amid pre-referendum negotiations, the M5S feared a further anti-democratic and German-centric turn for Eurozone members, which would deprive them of the last remnants of sovereignty left. In light of these prospects, the M5S called for an emergency plan to dismantle the Eurozone (Grillo, 2016b). Above all, the Brexit referendum was perceived as a direct indication of the critical situation faced by several member states and the downright failure of a 'one-size-fits-all' governance model of the EU (Grillo, 2016c). In the wake of the UK referendum, the M5S interpreted the result as a 'victory for direct democracy' (Grillo, 2016d); a way to sanction the failure of the politics of austerity, which prioritised the interests of banks and finance over those of its peoples, and the selfishness of other member states during the migrant crisis (Grillo, 2016e). Grillo's party's prognostic framing of Brexit was not entirely consistent, however: while the M5S originally advocated the opportunity to renegotiate EU membership and exit from the Eurozone (Grillo, 2016c), it successively backtracked on these demands (Grillo, 2016f).

In his reaction to the referendum outcome, SP leader Emile Roemer argued that 'the outvote of the British proves that the European project cannot survive without support of the population. If the EU does not learn from Brexit, and the undemocratic European integration continues, this will definitely initiate a domino-effect' (SP, 2016). According to the SP, Brexit 
provided an opportunity to make Europe less neo-liberal and more democratic; 'away from the Europe of mutual competition and [towards] building a slimmed-down EU. A New Union, of cooperation between countries, instead of a Union with diktats from Brussels' (SP, 2016). The frames the SP used in reaction to Brexit thus related to sovereignty and legitimacy, as well as socioeconomic questions. Yet in its manifesto for the 2017 parliamentary election, Brexit was not mentioned a single time, although the SP did propose to hold a referendum on a revised EU Treaty (SP, 2017: 53).

The PVV showed more enthusiasm for Brexit and congratulated the British with 'Independence Day'. The party wrote in its newsletter: 'Great Britain shows Europe the way towards the future and liberation. It is now time for a new start, depending on one's own strength and sovereignty. Also in the Netherlands' (PVV, 2016c). According to the PVV, the Dutch deserved their own referendum as soon as possible. In the parliamentary debate on Brexit, Wilders spoke of a momentous event: 'the UK chose for Brexit, for national sovereignty, for independence and against the almighty Brussels, the EU-super state and all those Europhile politicians' (PVV, 2016d). According to Wilders, the referendum result showed that citizens no longer tolerated the arrogance of the elites, who had ignored the ordinary men and women. For the PVV, then, Brexit highlighted the illegitimate character of the EU and the unresponsiveness of political elites, and the party repeated its desire to return sovereignty back where it belonged: the nation-state. Similar to the SP, however, Brexit hardly featured in the PVV's campaign for the 2017 parliamentary election.

Table 2. Populist Eurosceptic frames in the face of the multiple crises

\begin{tabular}{|c|c|c|c|}
\hline \multirow{2}{*}{ Parties } & \multicolumn{3}{|c|}{ Frames } \\
\hline & Great Recession & Migrant crisis & Brexit \\
\hline Northern League & $\begin{array}{ll}\text { - } & \text { Legitimacy } \\
\text { - } & \text { Sovereignty } \\
\text { - } & \text { Cultural } \\
\text { - } & \text { Socioeconomic } \\
& \text { (since 2014) } \\
\end{array}$ & $\begin{array}{ll}\text { - } & \text { Legitimacy } \\
\text { - } & \text { Cultural }\end{array}$ & $\begin{array}{ll}\text { - } & \text { Sovereignty } \\
\text { - } & \text { Legitimacy } \\
\text { - } & \text { Socioeconomic }\end{array}$ \\
\hline 5 Star Movement & $\begin{array}{ll}\text { - } & \text { Socioeconomic } \\
& \text { (since 2011) } \\
\text { - } & \text { Legitimacy } \\
\text { - } & \text { Sovereignty }\end{array}$ & $\begin{array}{ll}\text { - } & \text { Legitimacy } \\
\text { - } & \text { Cultural }\end{array}$ & $\begin{array}{ll}\text { - } & \text { Sovereignty } \\
\text { - } & \text { Legitimacy } \\
\text { - } & \text { Socioeconomic }\end{array}$ \\
\hline Socialist Party & $\begin{array}{ll}\text { - } & \text { Socioeconomic } \\
\text { - } & \text { Legitimacy } \\
\text { - } & \text { Sovereignty }\end{array}$ & $\begin{array}{l}\text { None (pro- } \\
\text { cooperation) }\end{array}$ & $\begin{array}{l}\text { - Sovereignty } \\
\text { - Legitimacy }\end{array}$ \\
\hline
\end{tabular}




\begin{tabular}{|c|c|c|c|}
\hline Party for Freedom & $\begin{array}{ll}\text { - } & \text { Socioeconomic } \\
& \text { (since 2012) } \\
\text { - } & \text { Cultural } \\
\text { - } & \text { Legitimacy } \\
\text { - } & \text { Sovereignty }\end{array}$ & - Legitimacy & $\begin{array}{ll}\text { - } & \text { Sovereignty } \\
\text { - } & \text { Legitimacy }\end{array}$ \\
\hline
\end{tabular}

The PVV thus mainly used sovereignty and legitimacy frames, whereas the framing of the Italian parties and the SP extended also to the socioeconomic sphere. The discursive evolution among Italian populist parties may be partly attributed to the structural fiscal and economic problems experienced by their country. Consequently, the EU and the compliant pro-European elites were still blamed for the Great Recession at the time of the Brexit referendum.

\section{Discussion and conclusions}

As typical opponents of European integration, and actors feeding on real or perceived crises, populist parties could take advantage of the multiple crises hitting the EU. The Great Recession, migrant crisis, and Brexit arguably lent credence to their dismissal of the EU as a malfunctioning apparatus lacking public support and democratic legitimacy. Populist parties could be expected to mould their anti-EU discourse in response to the events as they unfolded. At the same time, populist parties' responses were unlikely to be uniform, not least in view of their varying ideological profiles, as well as dissimilarities in the way the crises affected their specific national contexts.

As far as the relationship between Euroscepticism and crises is concerned, our enquiry revealed that populist parties do not necessarily reconcile the two in a consequential manner. Populist Eurosceptic actors do not promptly, nor automatically, blame 'Europe' amid crises with a marked European trait. Three of the four parties we studied remained essentially soft Eurosceptic (SP) or did not explicitly cross the hard-Eurosceptic ladder (LN and M5S); only the Dutch PVV started calling for a Dutch withdrawal from the EU from 2012 onwards. Crises are then primarily constructs performed by populist Eurosceptic actors. This was evident during the Great Recession, which in three of our cases only slowly translated into the expected socioeconomic framing of Euroscepticism.

On the other hand, while the construction and prioritisation of frames is dependent on strategic choices and contextual idiosyncrasies, populist Euroscepticism certainly proved a common denominator across cases and crises. This may demonstrate that the easiest way to undermine the credibility of the European project, from a populist perspective, is to sustain a 
systematic criticism of its undemocratic character and inability to weather different crises. As we have already mentioned, the legitimacy frame serves as a powerful stratagem to articulate populist anti-establishment views at the transnational level.

There were also certain predictable patterns in populist party reactions, with socioeconomic frames (eventually) featuring in their discourse after the economic downturn, and legitimacy and sovereignty frames central to their reactions to Brexit. Concerning the latest crisis, all populist parties used the opportunity to argue that the voice of the people trumped the unresponsive decisions of the national and European elites. We furthermore saw that they used Brexit to reiterate their discontent with the handling of the preceding crises. The LN traced the causes of Brexit in the centralising attempts of Brussels and European lobbies; the M5S interpreted the outcome as a direct result of EU mismanagements of the economic and migrant crises; the PVV and SP argued that Brexit was borne out of the elites' more general disregard of the will of the people. What is clear, however, is that Brexit did not constitute a very prominent theme for long in the discourses of the Italian and Dutch populist parties. If anything, the uncertain outcome of Brexit talks and lack of appetite for withdrawal outside the UK, have probably led parties of the populist camp to reconsider the hardest portions of their Eurosceptic agendas.

At the risk of oversimplifying an otherwise composite picture, we can argue that longstanding distinctions between radical-right and radical-left populist Euroscepticism were largely preserved (see Hooghe et al., 2002; De Vries and Edwards, 2009). All populist parties used legitimacy and sovereignty frames, yet cultural frames were mostly used by the radical right (LN and PVV), whereas the left-wing SP stuck to a socioeconomic framing criticising the neoliberal character of European integration - while notably welcoming a European solution to the migrant crisis. An ideologically hybrid organisation such as the M5S virtually sat somewhere in between: while the dominant framing during the Great Recession remained socioeconomic, it took nativist cultural tones amid the migrant crisis.

The relationship between ideology and framing should however not be overstated. Socioeconomic frames were used also by the radical right PVV and LN, although their more specific arguments varied, presumably due to the different impact of the economic crisis in their respective countries. The $\mathrm{LN}$ - similar to the M5S - focused in particular on the Euro, which was seen as the cause of much of the hardship endured by the Italian population. The PVV similarly lamented the negative consequences of the crisis for Dutch citizens, but also directed much of its criticism towards the transfers by the Dutch government to the EU and financially unstable 
countries - supposedly responding to public dissatisfaction with the country's 'creditor' role during the crisis.

At the same time, the issue of immigration was not the exclusive prerogative of rightwing populists. The left-wing SP opposed free movement of labour if this meant unfair competition and exploitation of workers. The party, however, framed the issue more in a socioeconomic than cultural sense. The SP's analysis of the 'Great Recession' also lacked the explicit 'welfare chauvinist' narrative that characterised the PVV - i.e. that money spent abroad should instead be saved for Dutch citizens.

Future research should focus on the impact of populist Euroscepticism. In our cases no true deviation from the pro-EU route seems to have taken place among mainstream actors, with the only exception being Berlusconi's FI in Italy (McDonnell, 2014). FI's Eurosceptic move may well have been a reaction to the growing popularity of Salvini within the Italian right bloc. While political alliances with populist Eurosceptics are very much in flux ahead of the 2018 elections, Berlusconi's FI seems again set on a Europhile route within the boundaries of the European People's Party (Corriere della Sera, 2017).

While the Dutch Liberals (VVD) and Christian Democrats (CDA) have voiced Eurosceptic arguments in recent years, it is difficult to gauge the extent to which the parties were inspired by their electoral competitor, the PVV. In any case, all Dutch mainstream parties remain far removed from Wilders' hard-Eurosceptic position. Since Wilders lately turned down the volume on Europe, and the SP's Euroscepticism remains relatively soft, there have also been few incentives for mainstream parties to radically alter their positions, or to translate their Eurosceptic rhetoric into concrete actions while in government. The coalition agreement signed in October 2017 between VVD, CDA, and two other parties, contained few traces of Euroscepticism.

Perhaps more suggestive is the interchange between populist Eurosceptics. At least the Italian case presents us with a scenario in which the LN and M5S were subject to mutual influence: Grillo's party was the first to elaborate on exit from the Eurozone - a theme taken up by the LN only under Salvini's leadership - and the presence of the populist Eurosceptic counterpart in the discourse of each party clearly substantiates a competition on the basis of common frames. On the Dutch radical right, meanwhile, Wilders is currently joined by a populist Eurosceptic newcomer, Forum for Democracy (FvD), which has broken the PVV's monopoly on hard Euroscepticism.

The analysis of populist Eurosceptic trajectories in Italy and the Netherlands answered a number of questions on the responsiveness of these actors as well as their frame construction 
and bridging mechanisms. The relationship between populism, Euroscepticism, and crises is however far from straightforward and constantly exposed to empirical and conceptual challenges. It is only by pinpointing these aspects in a systematic way that a thorough understanding of these organisations can be ultimately attained. 


\section{References}

Akkerman, A., C. Mudde and A. Zaslove (2014) 'How Populist Are the People? Measuring Populist Attitudes in Voters'. Comparative Political Studies, 47(9), 1324-1353.

ALDE (2017) 'Statement of the ALDE Group on cooperation with the Five Star Movement'. Available from: http://alde.eu/en/news/801-statement-of-the-alde-group-on-cooperation-with-thefive-star-movement/.

Canovan, M. (1999) 'Trust the People! Populism and the Two Faces of Democracy'. Political Studies, $47(1), 2-16$.

Corriere della Sera (2017) 'Asse tra Berlusconi e il leader del Ppe «Il centrodestra vince in Europa»'. Available from: http://www.corriere.it/politica/17_settembre_28/asse-berlusconi-leader-ppeil-centrodestra-vince-europa-5934d832-a489-11e7-b9ac-71d7c26035bb.shtml

De Jong, D. (2013) 'Syrische Vluchtelingen Verdienen Betere Opvang'. Available from: https://www.sp.nl/opinie/dennis-jong/2013/syrische-vluchtelingen-verdienen-betereopvang.

della Porta, D., J. Fernandez, H. Kouki, and L. Mosca (2017) Movement Parties against Austerity. Cambridge: Polity.

De Vries, C., and E. Edwards (2009) 'Taking Europe to Its Extremes: Extremist Parties and Public Euroscepticism'. Party Politics, 15(1), 5-28.

Economist (2016) 'Forming an orderly queue. Europe's migrant crisis'. Available from: https://www.economist.com/news/briefing/21690066-europe-desperately-needs-controlwave-migrants-breaking-over-its-borders-how.

Eurostat (2016) 'Statistics by theme'. Available at: http://ec.europa.eu/eurostat/data/browsestatistics-by-theme.

Grillo, B. (2007) 'Stop ai fondi europei all'Italia'. Available from: http://www.beppegrillo.it/2007/11/stop ai fondi e.html.

Grillo, B. (2009a) 'Banche di governo e di rapina'. Available from: http://www.beppegrillo.it/2009/02/banche di governo e di rapina/index.html.

Grillo, B. (2009b) 'Le banche non sono mai in crisi'. Available from: http://www.beppegrillo.it/2009/10/la banche non s.html.

Grillo, B. (2011a) 'Comunicato politico numero quarantacinque', available at: http://www.beppegrillo.it/2011/08/elezioni on lin.html.

Grillo, B. (2011b) 'La Guerra delle Monete'. Available from: http://www.beppegrillo.it/2011/01/la guerra delle monete/index.html.
Grillo,
B.
(2011c)
'Eurogermania'.
Available
from:

http://www.beppegrillo.it/2011/02/eurogermania/index.html. 
Grillo, B. (2011d) 'Referendum per l'euro'. Available from: http://www.beppegrillo.it/2011/12/referendum per/index.html.

Grillo, B. (2012) 'Il tabù dell'euro'. Available from: http://www.beppegrillo.it/2012/04/quando si mette/index.html.

Grillo, B. (2013a) ‘Passaparola - La sovranità dei popoli europei - di Nigel Farage'. Available from: http://www.beppegrillo.it/2013/08/passaparola - la sovranita dei popoli europei di nigel farage.html.

Grillo, B. (2013b) 'Reato di clandestinità'. Available from: http://www.beppegrillo.it/2013/10/reato di clandestinita.html.

Grillo, B. (2014a) ‘\#FUORIDALL€URO’. Available from: http://www.beppegrillo.it/fuoridalleuro.

Grillo, B. (2014b) 'Immigrazione, il M5S al lavoro in UE'. Available from: http://www.beppegrillo.it/2014/09/immigrazione il m5s al lavoro in ue.html.

Grillo, B. (2015a) 'Referendum sull'euro: consegna delle firme in Senato', available at: http://www.beppegrillo.it/2015/06/referendum sulleuro consegna delle firme.html.

Grillo, B. (2015b) 'La pazzia dell'euro \#fuoridalleuro'. Available from: http://www.beppegrillo.it/2015/01/la pazzia delleuro fuoridalleuro.html.

Grillo, B. (2015c) 'L'ipocrisia dell'Europa che non inverte rotta. \#bastatragedie in mare'. Available from: http://www.beppegrillo.it/movimento/parlamentoeuropeo/2015/05/lipocrisiadelleurop.html.

Grillo., B. (2015d) 'Cronache da Ventimiglia - Alice Salvatore'. Available from: http://www.beppegrillo.it/2015/06/cronache da ventimiglia - alice salvatore.html.

Grillo, B. (2015e) 'Quattro proposte sull'immigrazione, di Vittorio Bertola'. Available from: http://www.beppegrillo.it/2015/08/quattro proposte sullimmigrazione di vittorio bertola.h $\underline{\mathrm{tml}}$.

Grillo, B. (2016a) 'Emergenza immigrati: l'accordo dell’Europa con la Turchia è illegale'. Available from: http://www.beppegrillo.it/movimento/parlamentoeuropeo/2016/04/emergenza-profughil.html.

Grillo, B. (2016b) 'Il referendum in UK spaccherà l'Europa, prepariamoci al piano B \#brexit'. Available from:

http://www.beppegrillo.it/2015/11/il referendum in uk spacchera leuropa prepariamoci al piano b brexit.html.

Grillo, B. (2016c) 'Dieci cose da sapere sulla Brexit'. Available from: http://www.beppegrillo.it/2016/05/dieci cose da s.html.

Grillo, B. (2016d) 'Brexit, cosa succede adesso (spiegato bene)'. Available from: http://www.beppegrillo.it/2016/06/brexit cosa suc.html.

Grillo, B. (2016e) 'La UE o cambia o muore'. Available from: http://www.beppegrillo.it/2016/06/la ue o cambia o muore.html. 
Grillo, B. (2016f) 'Brexit or Bremain? Oggi si vota. Ecco dieci punti per capire meglio'. Available from: http://www.beppegrillo.it/2016/06/brexit o breima.html.

Helbling, M., D. Hoeglinger, and B. Wüest (2010) 'How Political Parties Frame European Integration'. European Journal of Political Research, 49(4), 495-521.

Hooghe, L., G. Marks, and C. Wilson. 2002. Does Left/Right Structure Party Positions on European Integration? Comparative Political Studies, 35(8), 965-989.

Huysseune, M. (2010) 'A Eurosceptic Vision in a Europhile Country: The Case of the Lega Nord'. Modern Italy, 15(1), 63-75.

Ignazi, P. (2005) 'Legitimation and Evolution on the Italian Right-Wing: Social and Ideological Repositioning of Alleanza Nazionale and the Lega Nord'. South European Society and Politics, 10(2), 333-349.

LN (2004) 'Programma per le Elezioni Europee del 2004'. EP election manifesto.

LN (2009) 'Proposte e Obiettivi'. Programmatic document.

LN (2013) 'Programma Elezioni Politiche 2013'. Election manifesto.

LN (2014a) 'Elezioni Europee 25 Maggio 2014. Programma Elettorale'. EP election manifesto.

LN (2014b) ‘Basta €uro. Come Uscire dall'Incubo’. Programmatic document.

LN (2015a) 'Immigrazione: Linee Guida Generali Lega Nord'. Programmatic document.

LN (2015b) 'Francia, Crosio (ln), Europa incapace di arginare fanatismi'. Available from: http://www.leganord.org/notizie/le-news-2/13733-francia-crosio-ln-europa-incapace-diarginare-fanatismi.

LN (2015c) 'Copenaghen: Fedriga (ln), Europa vulnerabile per colpa del buonismo di sinistra'. Available from: $\quad$ http://www.leganord.org/notizie/le-news-2/13923-copenaghen-fedriga-ln-europavulnerabile-per-colpa-del-buonismo-di-sinistra.

LN (2015d) 'Immigrazione, Molteni (ln): pacchetto Bruxelles è eurofregatura'. Available from: http://www.leganord.org/notizie/le-news-2/14366-immigrazione-molteni-ln-pacchettobruxelles-e-eurofregatura.

LN (2015e) ‘Lega, Calderoli: "Per salvare la cultura europea servono confini e sovranità nazionale, come chiedono Salvini, Le Pen, Strache e Wilders"'. Available from: http://www.leganord.org/notizie/le-news-2/14804-lega-calderoli-per-salvare-la-culturaeuropea-servono-confini-e-sovranita-nazionale-come-chiedono-salvini-le-pen-strache-ewilders.

LN (2016a) 'Brexit: centinaio, popoli scelgono liberta' da ue. Noi vogliamo lo stesso.a ottobre renxit'. Available from: http://www.leganord.org/notizie/le-news/15354-brexit-centinaio-popoliscelgono-liberta-da-ue-noi-vogliamo-lo-stesso-a-ottobre-renxit.

LN (2016b) 'Brexit: giorgetti, europa senza democrazia, suo destino sia deciso dai popoli In questi giorni parole aberranti'. Available from: www.leganord.org/notizie/le-news/15360-brexit-giorgettieuropa-senza-democrazia-suo-destino-sia-deciso-dai-popoli-in-questi-giorni-parole-aberranti. 
LN (2016c) 'Brexit: fedriga, ora distruggere europa delle lobby'. Available from: www.leganord.org/notizie/le-news/15355-brexit-fedriga-ora-distruggere-europa-delle-lobby. Lucardie, P. and G. Voerman (2012) Populisten in de Polder. Amsterdam: Boom.

M5S

Programma.

Available

from:

http://www.beppegrillo.it/iniziative/movimentocinquestelle/Programma-Movimento-5-

Stelle.pdf.

McDonnell, D. (2014) 'Despite Renzi's Triumph, Euroscepticism is Alive and Well in Italy'. Available from: $\quad$ http://www.policy-network.net/pno detail.aspx?ID=4669\&title=Despite-Renzistriumph-Euroscepticism-is-alive.

Moffitt, B. (2015) 'How to Perform Crisis: A Model for Understanding the Key Role of Crisis in Contemporary Populism'. Government and Opposition, 50(2), 189-217.

PVV (2010) Partij voor de Vrijheid: De agenda van hoop en optimisme. Een tijd om te kiezen. PVV 20102015. Parliamentary election manifesto.

PVV (2012) Hun Brussel, Ons Nederland. Verkiezingsprogramma 2012-2017. Parliamentary election manifesto.

PVV (2014) Verkiezingsprogramma Europees Parlement 2014. European Parliament election manifesto.

PVV (2015a) 'PVV: Grenzen Dicht!'. Newsletter article, 1 October 2015.

PVV (2015b) 'Inbreng Geert Wilders bij vluchtelingendebat'. Newsletter article, 14 October 2015.

PVV (2016a) 'Videoboodschap Geert Wilders: Mannelijke asielzoekers opsluiten in AZC's', newsletter article, 18 January 2016.

PVV (2016b) 'Inbreng Geert Wilders bij het debat over de instroom van asielzoekers', newsletter article,

12 February 2016.

PVV (2016c) 'PVV feliciteert Britten met Independence Day!', newletter article, 24 June 2016.

PVV (2016d) 'Inbreng Geert Wilders debat over Brexit', newsletter article, 27 June 2016.

PVV (2017a) Nederland weer van ons! Concept-verkiezingsprogramma PVV 2017-2021. Parliamentary election manifesto.

PVV (2017b) 'Inbreng Geert Wilders debat over het eindverslag van de informateur'. Newsletter article, 12 October 2017

Scharpf, F. (1999) Governing in Europe. Oxford: Oxford University Press.

Schumacher, G. and M. Rooduijn (2013) 'Sympathy for the "Devil"? Voting for Populists in the 2006 and 2010 Dutch General Elections'. Electoral Studies, 32(1), 124-133.

Snow, D.A., and R.D. Benford (1988) 'Ideology, Frame Resonance, and Participant Mobilization', in B. Klandermans, H. Kriesi, and S. Tarrow (eds.) From Structure to Action: Social Movement Participation Across Cultures. Greenwich, CT: JAI Press, pp. 197- 217. 
Snow, D.A., and R.D. Benford (1992) 'Master Frames and Cycles of Protest', in A.D. Morris and C.M. Mueller (eds.) Frontiers in Social Movement Theory. New Haven, CT: Yale University Press, pp. 133-155.

Snow, D.A., E.B. Rochford Jr., S.K. Worden, and R.D. Benford (1986) 'Frame Alignment Processes, Micromobilization, and Movement Participation'. American Sociological Review, 51(4), 464481.

SP (1998) Tegengas! Verkiezingsprogramma van de Socialistische Partij 1998-2002. Parliamentary election manifesto.

SP (2006) Een beter Nederland, voor hetzelfde geld. Verkiezingsprogramma van de SP, 2006-2010. Parliamentary election manifesto.

SP (2009) Een beter Europa begint in Nederland. Programma van de SP voor the verkiezingen van het Europees Parliament 2009-2014. European Parliament election manifesto.

SP (2010) Een beter Nederland, voor minder geld. Verkiezingsprogramma SP 2011-2015. Parliamentary election manifesto.

SP (2012) Nieuw vertrouwen: verkiezingsprogramma SP 2013-2017. Parliamentary election manifesto. SP (2014) Superstaat nee. Samenwerking ja: tegen deze EU. Nee tegen deze EU. Europese verkiezingen 22 mei 2014. European Parliament election manifesto.

SP (2015) 'Vluchtelingen: Organiseer Opvang en Neem Zorgen Serieus'. Available from: https://www.sp.nl/nieuws/2015/10/vluchtelingen-organiseer-opvang-en-neem-zorgenserieus.

SP (2016) 'Roemer: 'Brexit Uitgelezen Kans voor Afgeslankt en Democratisch Europa”. Available from: https://www.sp.nl/nieuws/2016/06/roemer-brexit-uitgelezen-kans-voor-afgeslankt-endemocratisch-europa.

SP (2017) '\#PakDeMacht. Programma voor een Sociaal Nederland voor de Verkiezingen van 15 Maart 2017'. Parliamentary election manifesto.

Taggart, P. (2000) Populism. Buckingham: Open University.

Tarchi, M. (2015) Italia Populista. Dal Qualunquismo a Beppe Grillo. Bologna: Il Mulino.

Tronconi F. (ed.) (2015) Beppe Grillo's Five Star Movement. Farnham: Ashgate.

Van Kessel, S., and R. Castelein (2016) 'Shifting the Blame. Populist Politicians' use of Twitter as a Tool of Opposition'. Journal of Contemporary European Research, 12(2), 594-614.

Verbeek, B., and A. Zaslove (2016) 'Italy: A Case of Mutating Populism?'. Democratization, 23(2), 304323.

Vossen, K. (2011) 'Classifying Wilders: The Ideological Development of Geert Wilders and His Party for Freedom'. Politics, 31(3), 179-189.

Wilders, G. (2005) Groep Wilders. Onafhankelijkheidsverklaring, Groep Wilders Party Document. 